\title{
BODY COMPOSITION ANALYSIS IN WOMEN AGED 50-80 IN KUJAWSKO-POMORSKIE VOIVODESHIP
}

\author{
ANALIZA SKŁADU CIAŁA KOBIET \\ WOJEWÓDZTWA KUJAWSKO-POMORSKIEGO \\ MIĘDZY 50 A 80 ROKIEM ŻYCIA
}

\author{
${ }^{1}$ Sports Medicine Regional Center in Bydgoszcz, Poland \\ ${ }^{2}$ Department of Physiology, Nicolaus Copernicus University Collegium Medicum in Bydgoszcz, Poland \\ ${ }^{3}$ Chair and Clinic of Pediatrics, Allergology and Gastroenterology, Nicolaus Copernicus University \\ Collegium Medicum in Bydgoszcz, Poland
}

S u m m a r y

Obesity is a problem which is more and more common in Polish population. The reason for that is excessive energy delivery from food against the quantity used by organism, as well as too small physical activity. These factors lead to excessive increase of body fat quantity which has a detrimental impact on the health condition.

The purpose of the study is a body composition assessment in women aged 50-80 living in KujawskoPomorskie Voivodeship.

1902 female inhabitants of Kujawsko-Pomorskie Voivodeship participated in the study which was divided into six age groups. The fat mass level and the fat free mass level of the body was evaluated with the assistance of electrical bioimpedance method. The content of water in the organism and, indirectly, the basic metabolism level were also determined.

With age women exhibit the decrease of fat free body mass and water level in the organism; whereas the body mass and, at the same time, the body fat content are observed to increase for women between 50 and 70 years of age. Above the age of 70 this tendency is reversed and the body mass and the body fat level decline. It was also observed that with age the basic metabolism level systematically diminishes within the population.

\section{Streszczenie}

Otyłość to problem coraz częściej występujący w polskiej populacji. Przyczyną jest nadmierne dostarczanie energii z pokarmów w stosunku do ilości zużywanych przez organizm, a także zbyt mała aktywność fizyczna. Czynniki te prowadzą do nadmiernego zwiększenia ilości tkanki thuszczowej, niekorzystnie wpływającej na stan zdrowia.

Celem badania jest ocena składu ciała kobiet między 50 a 80 rokiem życia zamieszkujących województwo kujawskopomorskie.
W badaniu uczestniczyły 1902 mieszkanki województwa kujawsko-pomorskiego, które podzielono na sześć grup wiekowych. Oceniono u nich za pomocą metody bioimpedancji elektrycznej poziom masy tłuszczowej i beztłuszczowej ciała. Określono również zawartość wody w organizmie i pośrednio poziom podstawowej przemiany materii.

Wraz z wiekiem u kobiet następuje obniżenie beztłuszczowej masy ciała i poziomu wody w organizmie. Obserwuje się natomiast wzrost masy ciała i jednocześnie zawartości tkanki tłuszczowej u kobiet między 50 a 70 rokiem życia. 
Powyżej 70 roku życia tendencja ta ulega odwróceniu i dochodzi do spadku masy ciała i poziomu tkanki thuszczowej. Jednocześnie zaobserwowano, że wraz z wiekiem poziom podstawowej przemiany materii systematycznie ulega zmniejszeniu w populacji.

Key words: body composition, fat mass, BIA, elderly women Stowa kluczowe: skład ciała, masa tkanki tłuszczowej, analiza impedancji bioelektrycznej, kobiety w wieku starszym

\section{INTRODUCTION}

Within the last two decades there was an increase in scientific interest in elderly people. The reason for this situation is prolongation of life followed by the increase in the population of people over 60. In Poland as well as in Europe it is statistically estimated that life expectancy will rise from current 79.8 in women to 82.9 in 2035. Along with prolongation of life, health problems which are specific for this age group come into existence. One of basic diseases of elderly people is obesity which leads to other numerous medical complications. It is associated with an excess intake of calories and diminishing of the basic metabolism as well as the decrease in physical activity level, which is usually connected with withdrawal from job duties. It leads to being overweight and obesity regardless of race and age. Research shows that in 20021.4 billion people worldwide were touched by overweight and obesity [1,2], in 2005 this problem already referred to 1.6 billion people worldwide, out of whom 522 million were obese people [3]. The latest studies published in 2014 show that 2.1 billion people worldwide are overweight and 671 million people are obese [4].

Studies conducted on American population show even worse results. Being overweight or obese is a characteristic feature of people over 60 years old for $78.4 \%$ of male population and $68.6 \%$ of female population [5]. Polish research from 2011 shows that there are $54 \%$ of overweight people in the country and two years earlier the estimation was 52\%. In 2009 in $50-59$ years age group $43 \%$ people were overweight, $23 \%$ were obese; in age group 60-69, $44 \%$ were overweight and $28 \%$ were obese and in age group 70 $79,46 \%$ were overweight and $24 \%$ were obese. The percentage of the total number of women in 2009 weighing too much was $46.2 \%$, out of which $30.4 \%$ were overweight and $15.8 \%$ were obese. As for men, the numbers are even bigger, namely as much as $63.6 \%$, out of which $46.3 \%$ - overweight and $17.3 \%$ obese [6].

Apart from genetic factors and the hormonal state of the organism, obesity is influenced by nutrition, quantity and quality of physical activity. BMI, eva- luated by many authors, is used for population-based screening determination of the prevalence of cases of being overweight and obese.

Recently, Polish literature has indicated the lack of studies presenting the body fat and other body composition components level in elderly people of Kujawsko-Pomorskie Voivodeship. The only screening research published on the Internet by TGI of MilwardBrown Agency referring to 07.2015- 12.2015 of Kujawsko-Pomorskie Voivodeship shows that our rank is number 8 as far as the excess body mass in the country is concerned, with $47.99 \%$ of the citizens. In this respect, it seems to be of paramount importance to determine the elderly people's overweight level within the society in accordance with the respective body composition parameters division. The electrical bioimpedance method will prove to be useful while conducting measurements.

\section{MATERIAL AND METHODS}

1902 female participants took part in the study which was conducted in 2010-2011 on women participating in Senior Physical Activity Regional Programme of Kujawsko-Pomorskie Voivodeship. Women taking part in the study were informed about the purpose and methodology of the study and they endorsed written consents. All women were examined by a doctor assisted by a nurse. The examination included an interview, arterial blood pressure and heart contraction frequency measurement, EKG, lung auscultation, examining of reflexes, balance and color vision. Next, the physiotherapist (with a MA degree) measured height, body mass, waist and hips circumference, and the body composition with the TANITA SC 330 device. With the assistance of this device the basic body composition parameters were achieved, such as Muscle Mass in \% and kg, Fat Mass in $\%$ and $\mathrm{kg}$, Total Body Water, Body Mass Rate. All examinations were conducted in the afternoon, in rooms meeting the safety standards, in temperature 18 $22^{\circ} \mathrm{C}, 4$ hours after the last meal. 
The bioelectrical impedance method is characterized by the difference's evaluation between the electrical current conduction in the part representing water mass and the fat mass of the body. This method involves the measurement of the total resultant body electrical resistance which consists of the resistance and reactance phenomena [7]. Resistance refers to the electrical resistance process of particular organism tissues, while reactance is a derivative of cell membranes electrical volume, which due to their physical features act as condensers. The size of organism resistance is directly proportional to length (L) and proper resistance (p), and inversely proportional to its cross-section surface (A), whereas reactance is inversely proportional to electrical current frequency and system electrical volume. With respect to the fact that within an organism the particular structures are connected in series as well as collaterally, the device uses mathematical operations which give the following impedance formula:

$$
Z=\frac{X_{c} R}{\sqrt{X_{c}^{2}+R^{2}}}
$$

Due to the fact that a human organism is not homogenous and its resistance and electrical volume are changeable in particular tissues, one must be aware of the fact that water together with the electrolytes has a special property. Extracellular water as well as fat tissue do not demonstrate reactance but they have resistance. However, reactance comes into existence on cell membranes of tissues with a big water content which act as condensers [8]. Most of all, reactance has influence on a phase shift of the applied alternating current in the vectorial aspect by the phase angle, and resistance causes the voltage drop. Received during the measurement process, the outcome of the total system impedance resultant after mathematical transformations in the device allows the water value in the system to be received. This parameter, after the next mathematical transformations, allows calculation of the level of the other body composition values [9].

Due to the fact that during the examination a very low amperage current is applied to the human body below $1 \mathrm{~mA}$ - the whole process is extremely safe and it is conducted below sensibility threshold, especially in case of this measurement device model in which only two electrodes are employed under the examined person's feet. Because of placing the electrodes under the thick skinfold on the foot plantar part, it is of paramount importance to clean the feet and electrodes with alcohol before examination in order to remove contamination and ensure the best possible electrical conduction

On the basis of weight and height measurement results the BMI was calculated. The mean values of the BMI were: 27.5 in the first age group; 28 in the second; 28.1 in the third; 28.3 in the fourth; 28 in the fifth and 27.8 in the last one, respectively (Table I). According to WHO classification, on the basis of the BMI, women examined in the study in all age groups are within range of the first degree of overweight.

Table I. Characteristics of the subjects

\begin{tabular}{|c|c|c|c|c|c|c|c|c|c|c|}
\hline & \multirow[t]{2}{*}{$\begin{array}{l}\text { Age } \\
\text { Group }\end{array}$} & \multirow{2}{*}{$\begin{array}{c}\text { Number } \\
\text { of } \\
\text { subjects }\end{array}$} & \multicolumn{2}{|c|}{ Age (year) } & \multicolumn{2}{|c|}{$\begin{array}{l}\text { Body } \\
\text { height } \\
(\mathrm{cm})\end{array}$} & \multicolumn{2}{|c|}{$\begin{array}{c}\text { Body } \\
\text { weight }(\mathrm{kg})\end{array}$} & \multicolumn{2}{|c|}{ BMI } \\
\hline & & & Mean & SD & Mean & \begin{tabular}{|l|} 
SD \\
\end{tabular} & Mean & SD & Mean & \begin{tabular}{|l|} 
SD \\
\end{tabular} \\
\hline 1 & $50-54$ & 493 & \begin{tabular}{|l}
52.1 \\
\end{tabular} & \pm 1.6 & 162.1 & \pm 5.6 & 72.3 & \pm 13.1 & \begin{tabular}{|l|}
27.5 \\
\end{tabular} & \pm 4.5 \\
\hline 2 & $55-59$ & 650 & 57.2 & \pm 1.4 & 160.7 & \pm 5.1 & \begin{tabular}{|l|l|}
72.4 \\
\end{tabular} & \pm 12.4 & 28 & \pm 4.5 \\
\hline 3 & 60-64 & 527 & 61.8 & \pm 1.4 & 160.4 & \pm 5.3 & 72.3 & \pm 12.8 & 28.1 & \pm 4.7 \\
\hline 4 & $65-69$ & 152 & 66.6 & \pm 1.4 & 159.8 & \pm 6.2 & 72.3 & \pm 11.3 & \begin{tabular}{|l}
28.3 \\
\end{tabular} & \pm 4.2 \\
\hline 5 & $70-74$ & 61 & \begin{tabular}{|l|l}
71.4 \\
\end{tabular} & \pm 1.5 & 159.3 & \pm 5.7 & \begin{tabular}{|l|l}
71.3 \\
\end{tabular} & \pm 11.3 & 28 & \pm 3.9 \\
\hline & $75-79$ & 19 & \begin{tabular}{|l|l|}
76.4 \\
\end{tabular} & \pm 1.5 & 157.8 & \pm 7.8 & \begin{tabular}{|l|l|}
69.2 \\
\end{tabular} & \pm 10.9 & \begin{tabular}{|l|l|}
27.8 \\
\end{tabular} & \pm 4 \\
\hline
\end{tabular}

Table II. Characteristics of the subjects II

\begin{tabular}{|c|c|c|c|c|c|c|c|c|}
\hline & \multirow{2}{*}{$\begin{array}{c}\text { Age } \\
\text { Group }\end{array}$} & \multirow{2}{*}{$\begin{array}{l}\text { Number } \\
\text { of } \\
\text { subjects }\end{array}$} & \multicolumn{2}{|c|}{$\begin{array}{c}\text { Waist } \\
\text { circumference } \\
(\mathrm{cm})\end{array}$} & \multicolumn{2}{|c|}{$\begin{array}{c}\text { Hips } \\
\text { circumference } \\
(\mathrm{cm})\end{array}$} & \multicolumn{2}{|c|}{ WHR } \\
\hline & & & Mean & SD & Mean & SD & Mean & SD \\
\hline 1 & $50-54$ & 493 & 89.6 & \pm 11.5 & 105.1 & \pm 9.4 & 0.85 & \pm 0.1 \\
\hline 2 & $55-59$ & 650 & 91.1 & \pm 11.4 & 106.6 & \pm 9.5 & 0.85 & \pm 0.1 \\
\hline 3 & $60-64$ & 527 & 90.9 & \pm 11.1 & 106.7 & \pm 9.8 & 0.86 & \pm 0.1 \\
\hline 4 & $65-69$ & 152 & 91.9 & \pm 10.5 & 106.8 & \pm 9 & 0.86 & \pm 0.1 \\
\hline 5 & $70-74$ & 61 & 91.4 & \pm 10.1 & 107 & \pm 9.4 & 0.85 & \pm 0.1 \\
\hline 6 & $75-79$ & 19 & 91.1 & \pm 9.9 & 106.6 & \pm 9.5 & 0.85 & \pm 0.1 \\
\hline
\end{tabular}

\section{RESULT}

All participants of the study were tested with respect to the body composition evaluation. The body fat content measured in $\mathrm{kg}$ as well as assessed in percentage is on the rise from the youngest age group in which it is $26.1 \mathrm{~kg}(35.1 \%)$. In the second age group it is already $26.8 \mathrm{~kg}(36.1 \%)$, in the third age group - 
$27 \mathrm{~kg}(36.3 \%)$ and in the fourth group of women $65-69$ years old it is $27.1 \mathrm{~kg}(36.7 \%)$. The last two age groups show the decrease of fat tissue level and, respectively, in the 70-74 years age group it is $26.2 \mathrm{~kg}(36 \%)$ and in the last group $-24.3 \mathrm{~kg}(34.2 \%)$. The muscle mass in the examined groups of women is decreasing from $43.8 \mathrm{~kg}$ in the youngest group of 50-54 years to 43.9 in the group 74-79 years. The same tendency is shown in the water level in the organism, namely, in the youngest group the percentage is 45.2 ; and in the oldest one the percentage is 44.3 . The body mass rate level, like in case of the previous two indexes, is decreasing from $1392 \mathrm{kcal}$ in the group of women 50-54 years old to $1337 \mathrm{kcal}$ in the age group 75-79.

Table III. Study results „Body composition”

\begin{tabular}{|c|c|c|c|c|c|c|}
\cline { 4 - 7 } \multicolumn{1}{c|}{} & \multirow{2}{*}{$\begin{array}{c}\text { Age } \\
\text { Group }\end{array}$} & \multirow{2}{*}{ Number of subjects } & \multicolumn{2}{|c|}{ Fat Mass $(\%)$} & \multicolumn{2}{|c|}{ Fat Mass (kg) } \\
\cline { 4 - 7 } \multicolumn{1}{c|}{} & & Mean & SD & Mean & SD \\
\hline 1 & $50-54$ & 493 & 35.1 & \pm 6.6 & 26.1 & \pm 9.3 \\
\hline 2 & $55-59$ & 650 & 36.1 & \pm 6.1 & 26.8 & \pm 8.7 \\
\hline 3 & $60-64$ & 527 & 36.3 & \pm 6.2 & 27 & \pm 9.1 \\
\hline 4 & $65-69$ & 152 & 36.7 & \pm 5.5 & 27.1 & \pm 7.7 \\
\hline 5 & $70-74$ & 61 & 36 & \pm 5.7 & 26.2 & \pm 7.6 \\
\hline 6 & $75-79$ & 19 & 34.2 & \pm 7.4 & 24.3 & \pm 8.6 \\
\hline
\end{tabular}

Table IV. Study results "Body composition II"

\begin{tabular}{|c|c|c|c|c|c|c|c|c|}
\cline { 4 - 9 } \multicolumn{1}{c|}{} & \multirow{2}{*}{$\begin{array}{c}\text { Age } \\
\text { Group }\end{array}$} & \multirow{2}{*}{$\begin{array}{c}\text { umber } \\
\text { of }\end{array}$} & \multicolumn{2}{|c|}{$\begin{array}{c}\text { Muscle Mass } \\
(\mathrm{kg})\end{array}$} & \multicolumn{2}{c|}{$\begin{array}{c}\text { Total Body } \\
\text { Water }(\%)\end{array}$} & \multicolumn{2}{c|}{$\begin{array}{c}\text { Body Mass } \\
\text { Rate (kcal) }\end{array}$} \\
\cline { 4 - 9 } \multicolumn{1}{c|}{} & & & Mean & SD & Mean & SD & Mean & SD \\
\hline 1 & $50-54$ & 493 & 43.8 & \pm 4.4 & 45.2 & \pm 4.2 & 1392 & \pm 149.2 \\
\hline 2 & $55-59$ & 650 & 43.3 & \pm 4.3 & 44.4 & \pm 4 & 1375 & \pm 155.1 \\
\hline 3 & $60-64$ & 527 & 43 & \pm 4.1 & 44 & \pm 4 & 1366 & \pm 141.5 \\
\hline 4 & $65-69$ & 152 & 43 & \pm 4.2 & 43.7 & \pm 3.5 & 1363 & \pm 137.1 \\
\hline 5 & $70-74$ & 61 & 42.9 & \pm 4.6 & 43.2 & \pm 4.7 & 1356 & \pm 142.7 \\
\hline 6 & $75-79$ & 19 & 42.9 & \pm 4 & 44.3 & \pm 6 & 1337 & \pm 127.6 \\
\hline
\end{tabular}

\section{DISCUSSION}

The phenomenon of being overweight and obese is becoming more and more common. It is observed that middle-aged people enter elderly age already being visibly overweight and this phenomenon is progressing in the following years of their lives. The aging process generates changes in organism functioning, changes in metabolism, changes in internal organs working. The total energy expenditure is observed to drop and this decreasing tendency refers to all its components: basic metabolism, food's thermal action, physical activity. The consequence of this process is body composition changing, such as fat content increase.

It is paramount to conduct anthropometric measurements to determine the existence of overweight and obesity. One of the most commonly used anthropometric indicators is BMI (Quetelet). According to WHO, BMI value $\geq 30$ means obesity [10]. The Norwegian studies conducted in 1994-1995 in Tromso and North-Trondelag in 1995-1997 on a group of 19515 women and men showed that BMI above 25 within both sexes is associated with mortality increase. Additionally, together with BMI increase above 30, the percentage of women dying of cardiovascular, respiratory and cancerous diseases is advancing by several dozen with respect to women with BMI below 30 [11]. Nevertheless, this index should be determined only as a screening examination method or additionally, due to its low authoritativeness. This index does not determine the diversification between fat mass content and fat free mass content in the body. The relation between the fat content within the body and BMI depends on many factors: age, race, sex, hormonal condition, physical activity. Due to this fact it is vital to use more precise metrological methods which will consequently allow for detailed body composition parameters assessment. Such methods include, for instance: dual energy X-ray absorptiometry (DEXA), magnetic resonance method, isotopic labelling method or electrical bioimpedance method.

One of the most accurate methods nowadays, yet difficult to be used in screening - DEXA, was used in the Brazilian study involving 120 women with average age of $67.2 \pm 5.2$ determining fat tissue content on the level of $38.9 \pm 4.5(\mathrm{~kg})$ and $37.3 \pm 6.9(\%)$. BMI was estimated at $27.4 \pm 3.9$ [12].

In Italian study, also performed with DEXA method, in which 1423 women participated, average age was $67 \pm 5$ years and with age range of the examined group from 60 to 88 years, BMI was $26.2 \pm$ 3.5 with the 18.9 to 37.5 range. The fat content in $\mathrm{kg}$ was $23.8 \pm 6.7$ with the 7.9 to 47.8 range and the percentage of fat tissue was on the level of $37.7 \pm 6$ with the 18 to 55.4 range [13].

Also, Oyen and associates, conducting the studies with DEXA method in 1998-2000 on a group of 667 Norwegian women aged 71-74, determined fat mass $(\mathrm{kg})$ at $27.3 \pm 9.1$; fat mass in $\%$ at $40.9 \pm 7.7$ and also lean body mass $(\mathrm{kg}) 37.8 \pm 4$ and BMI at $26.3 \pm 3.9$ [14].

In our study conducted on a group of women from Kujawsko-Pomorskie Voivodeship we used the electrical bioimpedance method (BIA) which is noninvasive, fast in application and highly repetitive. The BIA measurement gives the possibility of the body 
composition evaluation as far as the fat mass and fat free mass content of the body is concerned. Other authors also willingly use this kind of method in their studies.

The example may be studies by Ihasz and associates who examined 1198 women in 3 different age groups out of which a group of 405 women between 61 and 80 years of age is comparatively interesting. According to authors, with age the level of fat tissue and BMI are on the increase and the muscle mass is on the decrease. In the above mentioned age group the results were as follows: for BMI: $29.36 \pm$ 4.85, muscle mass (\%) $32.56 \pm 3.89$ [15].

In the study by Arago et al. conducted on 158 healthy postmenopausal Caucasian women in two groups: study group and control group. Prior the tests, the body composition was examined and the results are as follows. In 70-person control group the average age of which was $56.90+4.96$, the results were, respectively, BMI $28.64+4.93, \mathrm{FM}(\mathrm{kg}) 27.54+8.40$, FM \% $39.24+7.04$, skeletal muscle mass $(\mathrm{kg}) 22.32+$ 2.90. The measurements were performed with the assistance of the bioimpedance method, with InBody 720 apparatus, Biospace, Seoul, Korea [16].

Similar results were achieved by Polish authors Wasiluk and Sawczuk while examining 180 women in Bielsko Biała with the average age of $65.3 \pm 4.68$. Using Akern BIA apparatus, they received the following results: BMI $28.3 \pm 4.5, \%$ of fat tissue content which was $40.5 \pm 7$, and FM (kg) $30.2 \pm 9.4$; LBM in $\mathrm{kg} 59.6 \pm 6.9$ and TBW in $\% 47.3 \pm 5.1$ [17].

In the German study conducted in 1994 in Giessen, Germany within Gisel project, the body composition was examined with Akern-RJL apparatus, BIA 101/S; Data Input, Frankfurt, Germany. A group of 164 women participated with the average age of $67.7+5.6$. Its results were as follows: BMI $26.4 \pm 3.7$; Fat Mass (kg) $30.3 \pm 6$; Fat Mass (\%) $44.6 \pm 3.7$; WHR 0.83 \pm 0.06 [18].

Another study was conducted in the capital of the Czech Republic - Prague - on a group of 53 women before the beginning of physical training. It was also performed with the bioimpedance method, with B.I.A. $2000 \mathrm{M}$ device, Data Input, Germany. The average age of women was $68.7 \pm 5$ and the results were, respectively: Body Mass (kg) $69.9+7.9$, Fat Mass (\%) $37.5+5.1$, Fat Free Body Mass $(\mathrm{kg}) 43.7+6.8$ [19].

Ignasiak et al. performed anthropometric parameters measurements I 114 physically inactive women aged $71 \pm 7.27$ and they received the following results: BMI $27.38 \pm 4.17$; Fat Mass (\%) $38.6 \pm 3.08$, Fat Mass (kg) $26.35 \pm 5.93$ and WHR $0.84 \pm 0.06$ [20].

Latorre et al. received a little different results in the study on 68 women with the average age of $72.76 \pm$ 4.68. They were as follows: BMI was $30.40 \pm 4.28$; Fat Mass (\%) $43.77+6.01$; Muscle Mass $21.12 \pm 2.67$ [21].

Also, the researchers coming from the majority of the other hemisphere countries willingly use the BIA devices as a tool for the body composition measurement. This is demonstrated by two Australian studies. The first one was conducted on 52 female volunteers aged 55-90 in New South Wales, in which the average age was $73.9 \pm 8.5$. The measurement was performed with the assistance of TANITA Body Composition Analyser device model BC 418 and the results were: BMI 27.9 \pm 5.2; Fat Mass (\%) $34.6 \pm 8.6$; FFM (kg) $48.9 \pm 8.5$ [22].

The other study was performed by SwedenLindblad et al. on a group of 51 women aged 83-96 in Goethenburg in 2008. The average age was $86.5 \pm 2.9$. The body composition was measured in the examined women with the electrical bioimpedance device Imp SFB7 Impedimed Brisbane, Australia. The results were as follows: BMI $24.8 \pm 3.6$; Fat Mass (kg) $21.4 \pm 5.8$; Fat Mass (\%) $33 \pm 5.6$; SMM (kg) $15 \pm 2.5$; SMM (\%) $23.8 \pm 3.3[23]$.

The Japanese also measured the body composition parameters in a group of 159 women with the bioimpedance method in Nishinomiya with InBody 430 device, Biospace, Tokyo, Japan. Their results were as follows: BMI $22.6 \pm 2.9$; Fat Mass (\%) $33 \pm 6.9$ [24].

The body mass analysis was also made by researchers in Brazil within the Health and Nutrition Survey study who divided the groups of participants into three age categories. In the first age group (6069.9 years) there were 211 women and their BMI was $26.3 \pm 0.33$ and WHR $0.85 \pm 0.01$; in the second group (70-79.9 years) there were 130 women and their BMI was $25.5 \pm 0.41$, WHR $0.87 \pm 0.01$; in the last age group (over 80) the number of women was 44 and their BMI $24.9 \pm 0.68$ [25].

So far, smaller groups of women have been taken into consideration during numerous studies. In the study presented by our team of researchers the body composition parameters of a big group of elderly women were determined, which allows the adiposity of the voivodeship population to be defined. 
By analyzing the components of women's bodies, the authors came to similar conclusions as in case of other studies in many parts of the world, in various ethnic groups. Namely, the conclusion is that with age the tendency of body mass increase appears, the same refers to the percentage increase of the fat tissue and BMI as well as the decrease of muscle mass. At the same time, the same worldwide studies show that during the late elderly age the increase of body mass and the fat tissue level are inhibited or even diminished $[26,27]$. This is also confirmed by the study conducted by our team. Within the first four age groups examined by our team, with age span between 50 and 70 years, the body mass, fat mass and WHR index were on the increase in respective groups. In the last two age groups the tendency for the increasing earlier values to be decreasing was observed, despite the fact that the examined group was smaller in number. Very interesting conclusions may be drawn upon analyzing the results of muscle mass of the participants. To put the matter more pointedly, with every passing year of life within this study, muscle mass was observed to decrease, which correlates with the basic metabolism decrease. Another interesting conclusion which confirms the worldwide studies is the fact referring to the decrease of the organism hydration with every passing year of life, which in case of women is in percentage dependent upon the organism fat tissue level, with the total body mass.

What needs to be taken into account is the fact that during analyses various types of devices operating on the basis of the BIA are used, which makes the comparison of particular results more difficult. The BIA measurement gives the possibility to assess the ratio of fat tissue to fat free tissue, which is vital from the point of view of health. Furthermore, each examination performed with this method is comparably authoritative.

The studies show that in order to fight obesity and overweight it is of paramount importance to apply a qualitatively and quantitatively balanced diet as well as physical activity. These factors are considered to be elements of the prophylaxis and also obesity treatment.

\section{ACKNOWLEGDMENTS}

This study was supported by Health Department of the Marshal Office of Kujawsko-Pomorskie Voivodeship.

\section{CONFLICT OF INTEREST}

The authors declare they have no conflict of interest.

\section{REFERENCES}

1. Elmadfa I. European Nutrition and Health Report 2009. Forum Nutr. 2009; 62.

2. Andreyeva T., Michaud P-C, van Soest A. Obesity and health in Europeans aged 50 years and older. Public Health. 2007; 121: 497-509.

3. WHO: The challenge of obesity in the WHO European Region. Fact sheet EURO 2005; 13: 1-4.

4. Marie Ng, Fleming Tom, Robinsosn Margaret, Thomson Blake et al. "Global, regional, and national prevalence of overweight and obesity in children and adults during 1980-2013: a systematic analysis for the Global Burden of Disease Study 2013. The Lancet 2014; Vol.384, No.9945,p.766-781.

5. Flegal KM, Caroll MD, Ogden CL, Curtin LR, Prevalence and trends in obesity among US adults, 1999 2008. JAMA. 2010; 3: 235-241.

6. Central Statistical Office „Health and Health Care In 2011" Warsaw 2012; publication available on http://www.stat.gov.pl/.

7. Hermann L. Über eine Wirkung galvanischer Ströme auf Muskeln und Nerven. Pflügers Archiv für die gesamte Physiologie 1871; 5:223-75.

8. Barnett A. Electrical method for studying water metabolism and translocation in body segments. Proc. Soc. Exp. Biol. Med. 1940; 44: 142-147.

9. Lukaski H.C, Bolonchuk W.W, Hal C.B, Siders W.A, Validation of tetrapolar bioelectrical impedance method to asses human body composition. J. Appl. Physiol. 1986; 60(4): 1327-1332.

10. WHO: Obesity: Preventing and managing the global epidemic. Report of a WHO consultation, Geneva, 1998.

11. Jan-Magnus Kvamme, Jostein Holmen, Tom Wilsgaard, Jon Florholmen, Kristian Midthjell, Bjarne K Jacobsen. Body mass index and mortality in elderly men and women: the Tromso and HUNT studies. Jornal Epidemiology Community Health 2012; 66: 611-617.

12. Francisco de Assis Guedes de Vasconcelos, Braian Alves Cordeiro, Cassiano Ricardo Rech, Edio Luiz Petroski. Sensitivity and specifity of the body mass index for the diagnosis of overweight/ obesity in elderly. Cad. Saude Publica, 2010; 26(8): 1519-1527.

13. Giorgio Bedogni, Angelo Pietrobelli, Steven B.Heymsfield, Athos Borghi, Anna Maria Manzieri, Pietro Morini, Nino Battistini, Gianfranco Salvioli. Is body mass index a measure of adiposity in elderly women? Obesity Research 2001; Vol. 9 No.1, 17-20.

14. Jannike Oyen, Gjesdal Clara Gram, Ottar Kjell Nygard, Stein Atle Lie, Haakon E. Meyer, Ellen Margrete Apalset, Per Magne Ueland, Eva Ringdal Pedersen, Oivind Midtuun, Stein Emil Vollset, Grethe S. Tell. Smoking and body fat mass in relation to bone mineral density and hip 
fracture: The Hordaland Health Study. Plos One 2014; Vol.9(3): e92882.

15. Ihasz F, Finn K.J, Lepes J, Halasi S, Szabo P. Body composition comparisons by age groups in Hungarian Adults. Int.J.Morphol. 2015; 33(3): 850-854.

16. Aragao F.A, Abrantes C.G, Gabriel R.F, Sousa M.F, Castelo-Branco C, Moreira M.H. Effects of a 12-month multi-component exercise program on the body composition of postmenopausal women. Climacteric 2013; 16:1-9.

17. Wasiluk Agnieszka, Jerzy Saczuk. Body composition of female senior inhabitants of Biała Podlaska vs their physical activity. Pol. J. Tourism 2013; 20: 68-78.

18. Petra M Luhrmann, Birgit M. Herbert, Monika Neuhauser-Berthold. Effects of fat mass and body fat distribution on resting metabolic rate in elderly. Metabolism 2001; 50(8): 972-975.

19. Vaclav Bunc, Pavel Hrasky, Marie Skalska. Body composition and aerobic fitness like a result of 6 months walking program in senior women. JMED Research 2014; DOI: $10.5171 / 2014.950910$

20. Ignasiak Z, Dąbrowska G, Żurek G. Fatness level in physically active and inactive female students at Wrocław University of the third age. Antropomotoryka 2007; 37: 67-73.

21. Latorre Roman P.A, Garcia Pinillos F, Huertas Herrador J.A, Cozar Barba M, Jimenez Munoz. Relationship between sex, body composition, gait speed and body satisfaction in elderly people. Nutrition Hospitalaraia 2014; 30(4): 851-857.

22. Charlton Karen, Batterham Marijka, Langford Kelly, Lateo Jenna, Brock Erin, Walton Karen, Lyons-Wall Philippa, Eisenhauer Katy, Green Nick, McLean Cameron. Lean body mass associated with upper body strength in healthy older adults while higher body fat limits lower extremity performance and endurance. Nutrients 2015; 7, 7126-7142.

23. Sweden- Lindblad A, Dahlin-Ivanoff S, Bosaeus I, Rothenberg E. Body composition and hand grip strength in healthy community-dwelling older adults in Sweden. Journal of Ageing Research \& Clinical Practise 2015; Vol.4(1): 54-58.
24. Ayaka Tsuboi, Mika Takeuchi, Mayu TerazawaWatanabe, Keisuke Fukuo, Tsutomu Kazumi. Association of cystatin with leptin and TNF-a In elderky Japanese women. Asia Pac. J.Cli.Nutr. 2015; 24(4): 626-632.

25. Debora Martins Dos Santos, Rosely Sichieri. Body Mass index and measures of adiposity among elderly adults. Rev Saude Publica 2005; 39(2).

26. Gurpreet Kaur, Kiran Bains, Harpreet Kaur. Body composition, dietary intake and physical activity level of sedentary adult Indian women. Food and Nutricion Sciences 2012; 3, 1577-1585.

27. Herng-Chia Chiu, Hsing Yi Chang, Lih-Wen Mau, TiKai Lee, Hong-Wen Liu. Height, weight and BMI of elderly people in Taiwan. Journal of Gerontology 2000; Vol.55A, No 11: 694-690.

Address for correspondence:

Andrzej Chęsy, Msc

Regionalny Ośrodek Medycyny Sportowej

ul.Tadeusza Rejtana 1

85-032 Bydgoszcz

e-mail: andrzej.chesy@gmail.com

Wojciech Sikorski, Katarzyna Dmitruk, Małgorzata

Tafil- Klawe: kizfizjol@cm.umk.pl

Gabriel Chęsy, Andrzej Rakowski, Paweł Rakowski: rehabilitacja.roms@wp.pl

Magdalena Kuśmierek: klped@cm.umk.pl

Received: 6.06.2016

Accepted for publication: 30.06.2016 